\title{
KOORDINASI PENGAWAS DAN KEPALA MADRASAH DALAM MENINGKATKAN PRESTASI KERJA GURU MIN 1 ACEH TENGGARA
}

\author{
Sabaruddin Ahmad \\ Kementerian Agama Kabupaten Aceh Tenggara \\ E-mail: sabaruddin.assingkily@gmail.com
}

\begin{abstract}
How to Cite:
Ahmad, S. (2020). Koordinasi Pengawas dan Kepala Madrasah dalam Meningkatkan Prestasi Kerja Guru MIN 1 Aceh Tenggara. Fitrah: Journal of Islamic Education, 1(2).168-179.
\end{abstract}

\begin{abstract}
ARTICLE HISTORY
Received :03 October 2020

Revised : 01 November 2020

Accepted : 21 December 2020

Published : 31 January 2021
\end{abstract}

\section{KEYWORDS:}

Coordination, Headmaster, Supervisor, Performance, Achievement

\section{ABSTRACT}

This paper aims to analyze the implementation and obstacles in coordination between supervisors and madrasah principals in improving the work performance of MIN 1 Aceh Tenggara teachers. The focus of this research discussion is the form of coordination, implementation, and coordination barriers between supervisors and principals of the madrasah. This research uses a qualitative approach with a descriptive-analytic method. Data collection was carried out by interviewing the participants of the MIN 1 Aceh Tenggara Teachers, and observation and documentation techniques. Furthermore, the data were analyzed using data reduction techniques, data presentation, and drawing conclusions. The validity of the data was tested by means of triangulation, both methods and sources. The results of this study indicate that (1) the form of coordination between supervisors and principals of madrasah is in the form of an annual program of activities on teacher performance; (2) The coordination includes observation and class visits, supervision meetings and teacher training; and (3) obstacles in coordination, namely competition for the quality of madrasah ibtidaiyah with basic education institutions at the same level (SD-IT, SD, and other similar institutions).

\section{ABSTRAK}

Tulisan ini bertujuan untuk menganalisa pelaksanaan dan hambatan dalam koordinasi antara pengawas dan kepala madrasah dalam meningkatkan prestasi kerja guru MIN 1 Aceh Tenggara. Fokus pembahasan penelitian ini yakni bentuk koordinasi, pelaksanaan dan hambatan koordinasi antara pengawas dan kepala madrasah. Penelitian ini menggunakan pendekatan kualitatif dengan metode deskriptif analitik. Pemerolehan data dilakukan dengan teknik wawancara dengan partisipan guru MIN 1 Aceh Tenggara, dan teknik observasi dan dokumentasi. Selanjutnya data dianalisis dengan teknik reduksi data, penyajian data dan penarikan kesimpulan. Keabsahan data diuji melalui cara triangulasi, baik metode maupun sumber. Adapun hasil penelitian ini menunjukkan bahwa (1) Bentuk koordinasi antara pengawas dan kepala madrasah yakni berupa program tahunan kegiatan terhadap kinerja guru; (2) Pelaksanaan koordinasi meliputi observasi dan kunjungan kelas, rapat supervisi dan pelatihan guru; dan (3) hambatan dalam koordinasi yakni persaingan mutu madrasah ibtidaiyah dengan lembaga pendidikan dasar setingkat (SD-IT, SD, dan lembaga se-derajat lainnya). 


\section{PENDAHULUAN}

Supervisi pendidikan merupakan komponen penting dalam upaya mewujudkan kualitas pendidikan dan mutu lulusan (Sumberdaya manusia) (Ulum, 2018). Sebab, pengawasan yang dilakukan oleh pengawas berdampak pada peningkatan kinerja dan prestasi guru (Ndapaloka, et.al., 2016). Hal ini didasari tugas mulia pengawas dalam memberi masukan, saran, kritik dan bimbingan atas hasil pengamatan dan supervisi pendidikan yang dilakukan pada lembaga di bawah pengawasannya.

Keselarasan kinerja pengawas yang berdampak baik pada guru, ditandai dengan perencanaan, pelaksanaan dan proses evaluasi yang baik dan tepat, baik dari aspek akademik maupun manajerial (Syawal \& Kartowagiran, 2013; Brotosedjati, 2011). Untuk itu, dibutuhkan koordinasi dan relasi yang baik antara pengawas dan pimpinan lembaga pendidikan (salah satunya, Madrasah).

Koordinasidanrelasiantarapengawas dan kepala madrasah dapat mensinergikan elemen-elemen yang ada di madrasah untuk melakukan tugas dan fungsi masing-masing secara integral, efektif dan efisien (Sudirman, et.al., 2017). Hal ini diimplementasikan dalam perwujudan visi, misi dan tujuan madrasah.

Hubungan antara pengawas dan kepala madrasah juga terbina melalui aspek kesamaan tugas yakni amanah UU Sisdiknas dalam upaya membantu dan membimbing guru di madrasah, baik dalam bentuk pembinaan guru, pelatihan guru, dan pendekatan supervisi untuk meningkatkan prestasi kerja guru (Mustafa, 2013). Berkaitan dengan tugas supervisi pengawas dan kepala madrasah terhadap para guru, terdapat realita paradoksal di lapangan (madrasah). Pengawas dan kepala madrasah yang seyogianya bekerjasama untuk membantu melayani guru melalui pendekatan supervisi, namun di sisi lain keduanya memperoleh beban kerja (tugas) yang harus dipenuhi secara administratif sehingga rentan untuk kurang berkoordinasi.

Menurut Hasibuan(2018), koordinasi antara pengawas dan kepala madrasah urgen dilakukan, guna mengintegrasikan tindakan supervisi terhadap guru dan pelaksanaan tugas yang tepat sasaran dan berorientasi pada tujuan. Lebih lanjut, Repina (2012) menyebutkan bahwa efektivitas koordinasi pengawas dan kepala madrasah ditandai dengan 2 (dua) aspek, yakni prestasi kerja guru dan prestasi siswa (lulusan). Hal ini mengacu pada indikator keberhasilan tugas pengawas dan kepala madrasah dalam memproduk SDM di madrasah. Madrasah sebagai sekolah plus dengan ditambahkan materi keagamaan Islam dalam kurikulum pendidikan, membutuhkan koordinasi yang baik antara pengawas dan kepala madrasah (Tanaka, 2018). Dalam konteks ini, koordinasi dimaksudkan sebagai wujud keselarasan tugas keduanya sesuai arah, sasaran dan tujuan madrasah. Seperti halnya di Madrasah Ibtidaiyah Negeri (MIN) 1 Aceh Tenggara, pimpinan madrasah dan pengawas senantiasa melakukan koordinasi dalam mewujudkan kesinambungan proses pendidikan melalui sistem pengawasan.

Efektivitas dan efisiensi sistem pengawasan dan koordinasi yang dilakukan di MIN 1 Aceh Tenggara ditandai dengan prestasi kerja guru madrasah di lingkungan Kementerian Agama (Kemenag) Kabupaten 
Aceh Tenggara dan prestasi siswa. Bahkan, tercatat sejak 2005 hingga sekarang, prestasi guru dan siswa MIN 1 Aceh Tenggara dinilai sebagai SDM teladan di lingkungan Kemenag Aceh Tenggara. Sejatinya, kajian tentang koordinasi pengawas dan kepala madrasah telah banyak diteliti oleh peneliti sebelumnya. Setidaknya, ada 9 (Sembilan) penelitian relevan dengan penelitian ini, di antaranya membahas koordinasi dari aspek pelaksanaan supervisi (Munawarah, 2017). Selanjutnya, ada penelitian relevan lainnya yang dilakukan oleh Maqdisiana (2014) tentang profil kinerja pengawas, penelitian Maujud (2018) tentang implementasi fungsi-fungsi manajemen, penelitian Adi (2016) terkait implementasi kompetensi manajerial, penelitian Hasbullah (2011) tentang persepsi guru terhadap koordinasi dan tugas supervisi kepala madrasah, penelitian Mufidah (2017) tentang implementasi manajemen berbasis madrasah, penelitian Hinawan (2017) terkait sinergitas pengawas dan kepala madrasah dalam upaya meningkatkan kinerja guru, penelitian Abubakar (2018) tentang upaya meningkatkan kualitas pembelajaran, dan penelitian Sudino, et.al., (2018) tentang upaya meningkatkan akreditasi madrasah.

Mencermati uraian di atas, terdapat "sisi kosong" untuk dikembangkan dalam penelitian pengawasan pendidikan di madrasah. Adapun aspek yang dimaksud adalah bentuk relasi, pelaksanaan koordinasi dan penyelesaian tugas serta hambatan yang diterima pengawas dan kepala madrasah dalam melaksanakan tugas supervisi, khususnya meningkatkan prestasi kerja guru. Untuk itu, dibutuhkan penelitian lebih lanjut terkait aspek tersebut, yang terangkum dalam judul "Koordinasi Pengawas dan Kepala Madrasah dalam Meningkatkan Prestasi Kerja Guru di MIN 1 Aceh Tenggara." Penelitian ini berupaya menganalisa bentuk pengembangan dan peningkatan prestasi kerja guru di setiap madrasah. Hal ini tentunya didukung dengan sistem pengawasan yang baik, koordinasi antara pengawas dan kepala madrasah yang efektif dan efisien, serta pemberian bimbingan yang objektif kepada setiap guru sesuai analisa kebutuhan masing-masing guru. Dengan demikian, SDM madrasah akan berkualitas dan mampu memenuhi kebutuhan masyarakat, terutama di eraabad ke-21 saatini. Adapun formulasiembahasan riset ini ditujukan pada kajian bentuk implementatif dari koordinasi antara pengawas dan kepala madrasah. Selanjutnya, dikemukakan pula bentuk hambatan dalam upaya koordinasi antar-supervisor.

\section{KAJIAN TEORI}

Koordinasi dalam konteks supervisi berarti kesamaan tugas yang meniscayakan hubungan saling memberi informasi dan menyepakati hal-hal tertentu (Ndraha, 2011: 290). Secara normatif, koordinasi meliputi upaya menyelaraskan, menyerasikan, menyeimbangkan dan menggerakkan kegiatan pengawasan pada arah dan tujuan tertentu. Lebih lanjut, Ndraha (2011) menambahkan bahwa koordinasi supervisi diartikan sebagai relasi, kerjasama dan job description atau pembagian kerja/tugas. Menurut Handoko (2003: 195), koordinasi memiliki peranan sebagai upaya integral dalam menyeimbangkan 
pengawasan individu dan kolaboratif, guna meningkatkan kualitas lembaga pendidikan. Lebih lanjut, Handayaningrat (2010) menjelaskan bahwa koordinasi erat kaitannya dengan komunikasi dan kepemimpinan. Senada dengan pendapat di atas, Hasibuan (2006) menerangkan bahwa koordinasi antara satu pihak dengan pihak lainnya merupakan bentuk integrasi komunikasi dan implementasi fungsi manajemen untuk mencapai tujuan tertentu dalam suatu organisasi atau lembaga. Koordinasi juga dipandang sebagai upaya penyederhanaan tugas atau beban kerja. Di mana pengawas dan kepala madrasah dalam konteks supervisi dapat saling bertukar informasi dan mencari alternatif solusi atas permasalahan yang diamati di madrasah.

Dengan demikian, koordinasi supervisi merupakan hal urgen yang dilakukan oleh supervisor (pengawas dan kepala madrasah) untuk membantu kinerja guru dan pemberdayaan SDM di madrasah.

Selanjutnya, prestasi kerja merupakan hasil evaluasi yang dilakukan oleh pihak tertentu terhadap kinerja berkala di suatu lembaga atau organisasi (Martoyo, 2012). Prestasi kerja guru, erat kaitannya dengan bagaimana seorang guru mampu dan mau menyelesaikan tugas kerjanya dengan baik dan etos kerja tinggi.

Menurut Rivai (2014), indikator pencapaian prestasi kerja guru dapat ditinjau dari beberapa aspek, yaitu sebagai berikut:

1. Kemampuan Teknis

Kemampuan teknis dimaksudkanbagaimana guru mampu mengaplikasi pengetahuan dan pengalamannya dalam proses pembelajaran.
2. Kemampuan Konseptual

Kemampuan konseptual dimaknai sebagai bentuk operasional yang dilakukan guru dalam memahami tugas, tanggungjawab dan kewajibannya.

3. Kemampuan Hubungan Interpersonal Kemampuan hubungan interpersonal penting bagi seorang guru untuk mencapai prestasi kerja yang baik. Sebab, relasi dan kemampuan bekerjasama dalam tim serta memotivasi peserta didik adalah inti dari kemampuan interpersonal.

\section{METODE PENELITIAN}

Penelitian ini menggunakan pendekatan kualitatif dengan metode deskriptif analitik. Adapun latar penelitian yaitu kegiatan koordinasi antara pengawas dan kepala madrasah di MIN 1 Aceh Tenggara.

Partisipan penelitian ini adalah kepala madrasah MIN 1 Aceh Tenggara dan Guru MIN 1 Aceh Tenggara, yakni Ani Susilawati, Sri Kumala Dewi, dan Nuraesah. Penentuan partisipan dilakukan memilih partisipan yang sesuai dengan demografi penelitian dan menyatakan bersedia memberikan data yang diperlukan dalam penelitian ini.

Pengumpulan data dilakukan dengan mewawancari partisipan dan informan, teknik observasi dan dokumentasi. Penjaminan validitas data penelitian dilakukan dengan triangulasi (metode dan sumber). Triangulasi dilakukan dengan membandingkan hasil wawancara antara satu partisipan dengan yang lainnya pada tema yang sama (Creswell, 2014). 


\section{HASIL DAN PEMBAHASAN PENELITIAN}

Sistematika penjelasan temuan dan pembahasan hasil penelitin akan diruntut berdasarkan masalah dan tujuan penelitian yakni bentuk koordinasi, pelaksanaan koordinasi, dan hambatan koordinasi. Secara jelas di uraikan berikut:

\section{Bentuk Koordinasi Antara Pengawas}

dan Kepala Madrasah di MIN 1 Aceh

\section{Tenggara}

Bentuk koordinasi antara pengawas dan kepala madrasah di MIN 1 Aceh Tenggara yakni berupa program tahunan kegiatan terhadap kinerja guru. Dalam hal ini, pengawas dan kepala madrasah juga berkoordinasi terkait waktu dan tempat layanan serta pengembangan sumberdaya guru. Sebagaimana dikemukakan guru MIN 1 Aceh Tenggara yakni Ibu Sri Kumala Dewi ketika diwawancarai berikut ini:

"pengawas dan kepala madrasah ada merumuskan prota (program tahunan) terkait kegiatan supervisi. Ini biasanya menyangkut pengawasan kinerja kami sebagai guru dalam proses pembelajaran, keterampilan kami guru-guru dalam menggunakan media, buat RPP dan silabus mengajar." (Wawancara dengan Ibu Sri Kumala Dewi, S.Pd., Guru MIN 1 Aceh Tenggara)

Senada dengan wawancara di atas, Ibu Ani menuturkan bahwa:

"pengawas dan kepala madrasah juga menyepakati kontrak dengan kami para guru tentang jadwal pembinaan dan pelayanan kemampuan guru selama 1 bulan sekali. Nanti, pas jadwal pelaksanaan, maka panitianya yang notabene dari guru saling kerjasama menyiapkan fasilitas pembinaan dan pelayanan guru." (Wawancara dengan Ibu Ani Susilawati, S.Pd., Guru MIN 1 Aceh Tenggara)
Berikut ditampilkan dokumentasi kegiatan koordinasi pengawas dan kepala madrasah serta para guru di MIN 1 Aceh Tenggara.

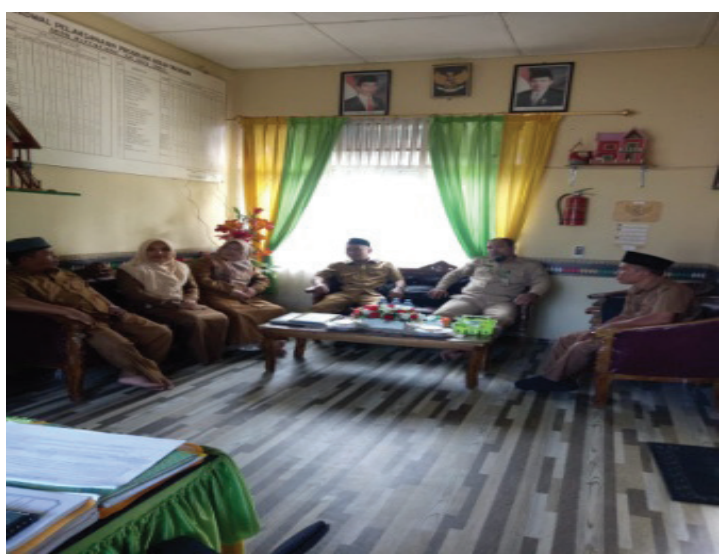

Gambar 1. Kegiatan Koordinasi Pengawas, Kepala Madrasah dan Guru MIN 1 Aceh Tenggara (Dokumentasi: Maiyatul Jannah Assingkily)

Melalui gambar dan kutipan wawancara di atas, dipahami bahwa deskripsi singkat dari bentuk koordinasi antara pengawas dan kepala madrasah mencakup program supervisi terhadap guru di madrasah, yakni mencakup (a) identifikasi kebutuhan guru, (b) mencari alternatif solusi, (c) program evaluasi dan (d) revisi (Agustina, 2017).

Lebih lanjut, bentuk program koordinasi antara pengawas dan kepala madrasah memperhatikan proses input dan output yang akan dituju dari program tersebut (Dukalang, 2019). Berdasarkan wawancara dengan Kepala Madrasah MIN 1 Aceh Tenggara menyebutkan bahwa:

"Sebenarnya, untuk program supervisi tahunan antara saya dan pengawas telah ada. Sebab, ini tertuang sebagai tugas tambahan kami dengan jabatan kepala madrasah dan pengawas madrasah. Akan tetapi, koordinasi sangat dibutuhkan, karena kami butuh penyesuaian waktu atau 
penetapan jadwal pembinaan guru untuk saling sinkron terkait data guru." (Wawancara dengan Kepala Madrasah MIN 1 Aceh Tenggara)

Berkaitan dengan wawancara di atas, Rosidah, et.al. (2014) berpendapat bahwa pembinaan yang dilakukan atas hasil koordinasi pengawas dan kepala madrasah terhadap para guru, ditujukan kepada upaya supervisi yang berkaitan dengan (1) pemeriksaan administrasi pembelajaran berupa RPP/Silabus guru, (2) penjadwalan supervisi bagi guru dan (3) pelatihan peningkatan kompetensi guru.

Ini menunjukkan bahwa koordinasi kepengawasan yang dilakukan merupakan bentuk implementatif dari fungsi manajemen (aspek controlling) di madrasah terhadap para guru (Syafaruddin, et.al., 2020; Hadi, 2019).

Menurut penuturan Bu Nuraesah, penetapan program tahunan supervisi di MIN 1 Aceh Tenggara dilaksanakan pada setiap awal semester ganjil. Senada dengan ini, Sumarto (2016) berpendapat bahwa penyusunan program tahunan di awal semester menambah efektivitas implementasi supervisi di madrasah. Dengan demikian, pelaksanaan supervisi baik manajerial maupun akademik di madrasah akan terlaksana dengan efektif dan efisien.

$$
\text { Berdasarkan uraian di atas, }
$$
dipahami bahwa bentuk koordinasi antara pengawas dan kepala madrasah di MIN 1 Aceh Tenggara yakni berupa koordinasi penyusunan program tahunan, penjadwalan supervisi dan upaya pembinaan guru baik secara manajerial (administratif) maupun akademik (kompetensi).
Pelaksanaan Koordinasi Antara Pengawas dan Kepala Madrasah di MIN

\section{Aceh Tenggara}

Pelaksanaan koordinasi antara pengawas dan kepala madrasah merupakan hal urgen dalam implementasi supervisi di madrasah, hal ini agar efektivitas dan efisiensi pelaksanaan kegiatan pendidikan berjalan dengan baik di madrasah (Marantika \& Dahlan, 2019; Assingkily \& Mesiono, 2019). Adapun pelaksanaan koordinasi yang dilakukan meliputi observasi dan kunjungan kelas, rapat supervisi dan pelatihan guru.

Berikut ditampilkan gambar pelaksanaan koordinasi yang dilakukan pengawas di MIN 1 Aceh Tenggara.

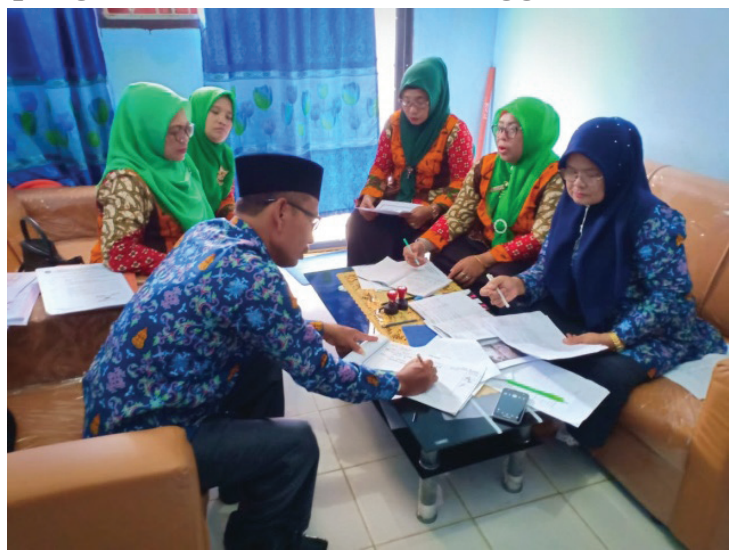

Gambar 2. Pelaksanaan Koordinasi Pengawas Madrasah di MIN 1 Aceh Tenggara (Dokumentasi: Widja Hadi)

Mengamati gambar di atas serta penjelasan dari supervisor di MIN 1 Aceh Tenggara, bahwa upaya pelaksanaan ini ditujukan agar perumusan program supervisi periode tahunan, dapat diimplementasikan secara objektif dan teratur. Hal ini meliputi pengaturan intensitas pembinaan terhadap guru, pelaksanaan kunjungan kelas secara observatif dan orientasi supervisiberdasarkan identifikasi kebutuhan guru (Ismahun, 2017; Zulfahmi, 2014; Abusmar, 2010). 
Menurut Rahmayanti, et.al. (2014), pelaksanaan supervisi atas dasar koordinasi pengawas dan kepala madrasah dapat dilaksanakan dengan 2 (dua) teknik, yakni individual dan kelompok. Senada dengan ini, Bu Nuraesah menyampaikan hal selaras seperti kutipan wawancara berikut ini:

"di madrasah, supervisi berjalan lancar. Sebagaimana kita ketahui sama-sama, bahwa ini semua karena adanya koordinasi antara pengawas dan kepala madrasah. Pelaksanaannya dilakukan dengan 2 cara biasanya, yakni individu seperti observasi dan kunjungan kelas, serta teknik kelompok seperti rapat supervisi dan pelatihan guru." (Wawancara dengan Bu Nuraesah, S.Pd.I., Guru MIN 1 Aceh Tenggara)

Kutipan wawancara di atas, menegaskan bahwa kedua teknik tersebut dibutuhkan oleh pengawas dan kepala madrasah dalam melaksanakan program supervisi sebagai bentuk objektivitas pengawasan (Makmurrizal, et.al., 2016). Sebab, ditinjau dari pengawasan pribadi supervisor dan pengawasan kolaboratif terhadap kegiatan pembelajaran yang dilaksanakan guru.

Menurut Ma'sum (2019), observasi dan kunjungan kelas dalam supervisi dapat mendorong guru untuk meningkatkan kompetensinya dalam mengajar dan meningkatkan cara belajar dari peserta didik. Lebih lanjut, Sahar (2015) berpendapat bahwa pelaksanaan observasi dan kunjungan kelas, lazimnya dilakukan dengan notifikasi dan tanpa notifikasi. Hal ini diyakini menjadikan guru dan siswa melakukan interaksi serta proses pembelajaran secara alamiah tanpa mengkhawatirkan intervensi dan pengawasan dari supervisor.
Berkaitan dengan hal di atas, Bu Ani Susilawati menyampaikan bahwa:

"...di madrasah, pelaksanaan supervisi berupa kunjungan kelas itu kadang diberitahu, dan kadangkadang pengawas tiba di kelas tanpa sepengetahuan kami. Ini membuat para guru tentunya bekerja secara optimal tidak dalam waktu insidental, tapi setiap harinya. Bahkan, kami para guru selalu mempersiapkan diri dengan baik, bahan ajar dengan baik, dan mengingatkan siswa untuk belajar dengan giat dan semangat." (Wawancara dengan $\mathrm{Bu}$ Ani Susilawati, S.Pd., Guru MIN 1 Aceh Tenggara)

Kutipan wawancara di atas, menegaskan bahwa teknik observasi dan kunjungan kelas berdampak baik terhadap proses pembelajaran dan interaksi gurusiswa di kelas. Ditambah lagi dengan teknik observasi dengan dan tanpa notifikasi menjadikan guru dan siswa selalu merasa diawasi dalam setiap proses pembelajaran di kelas.

Adapun pelaksanaan koordinasi pengawas dan kepala madrasah di MIN 1 Aceh Tenggara dalam bentuk kelompok, meliputi rapat supervisi dan pelatihan guru. Sebagaimana disampaikan oleh $\mathrm{Bu}$ Sri Kumala Dewi berikut ini:

"kalau di MIN 1 Aceh Tenggara, kami biasanya disupervisi juga dengan cara berkelompok, yakni dengan diadakannya rapat supervisi yang melibatkan guru, kepala madrasah dan pengawas, bahkan terkadang disertakan juga komite madrasah. Selain itu, diadakan juga pelatihan guru di ruang pelatihan untuk menindaklanjuti kelemahankelemahan yang kami temui sewaktu mengajar." (Wawancara dengan Bu Sri Kumala Dewi, S.Pd., Guru MIN 1 Aceh Tenggara) 
Kutipan wawancara di atas, mengonfirmasikan bahwa pelatihan guru dalam aspek kompetensi dan rapat supervisi menjadi alternatif tindak lanjut setelah pelaksanaan supervisi. Hal ini diorientasikan pada pemenuhan kebutuhan guru setelah diidentifikasi oleh supervisor.

Berkaitan dengan hal di atas, Ahmad (2019) menyebutkan bahwa pelaksanaan koordinasi antara pengawas dan kepala madrasah juga diarahkan pada upaya pengembangan SDM madrasah, baik prestasi kerja guru maupun mutu lulusan (peserta didik). Dengan demikian, pelaksanaan koordinasi berupa observasi, kunjungan kelas, rapat supervisi dan pelatihan guru merupakan upaya pihak madrasah (MIN 1 Aceh Tenggara) dalam memberikan pelayanan yang baik bagi pengembangan SDM di MIN 1 Aceh Tenggara.

\section{Hambatan dalam Koordinasi Pengawas} dan Kepala Madrasah di MIN 1 Aceh Tenggara

Koordinasi pengawas dan kepala madrasah merupakan upaya solutif dalam meningkatkanmutumadrasah(Fikriah,2019). Akan tetapi, dalam pengimplementasiannya, terdapat beberapa aspek yang menyebabkan koordinasi tersebut masih belum dapat berjalan dengan baik.

Hambatan atau rintangan yang diperoleh dalam koordinasi lazimnya disebabkan faktor internal dan eksternal madrasah (Bakar, 2011). Dengan demikian, dibutuhkan tim penjaminan mutu madrasah, sehingga arah atau orientasi koordinasi pengawas dan kepala madrasah dapat disinkronkan dengan baik (Alfiansyah, et.al., 2020).
Berikut ditampilkan gambar pertemuan atau diskusi singkat antara pengawas dan kepala madrasah.

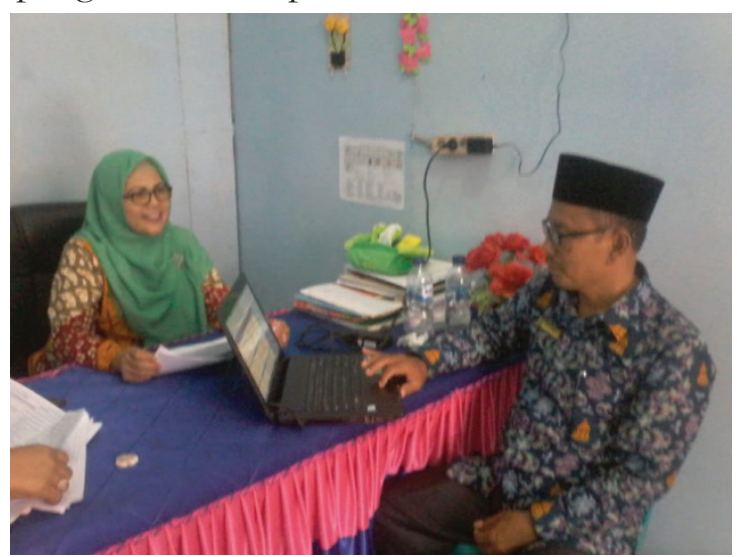

Gambar 3. Diskusi Pengawas dan Kepala Madrasah di MIN 1 Aceh Tenggara (Dokumentasi: Widja Hadi)

Mengamati gambar di atas, diketahui bahwa antara pengawas dan kepala madrasah sebagai supervisor kerap kali mengadakan pertemuan rutin untuk membahas mutu dan lulusan madrasah serta kompetensi guru sebagai "tonggak utama" dalam proses pembelajaran. Begitupun, terdapat hambatan yang dialami keduanya untuk saling berkoordinasi tentang keadaan madrasah (MIN 1 Aceh Tenggara).

Adapun hambatan dalam koordinasi yang diperoleh MIN 1 Aceh Tenggara lebih terasa pada aspek eksternal, yakni persaingan mutu madrasah ibtidaiyah dengan lembaga pendidikan dasar setingkat (SD-IT, SD, dan lembaga se-derajat lainnya). Kemunculan SD dengan konsep Islam terpadu merupakan bentuk lembaga pendidikan Islam "baru" yang menyajikan konsep-konsep yang dibutuhkan masyarakat di era saat ini.

Padahal, madrasah sebagai sekolah plus belajar agama, harus tetap menunjukkan eksistensi diri dengan menyajikan programprogram unggulan untuk memenuhi 
kebutuhan masyarakat (Tanaka, 2018). Untuk itu, peningkatan mutu lembaga di MIN 1 Aceh Tenggara memfokuskan prestasi kerja guru dan mutu lulusan sebagai target dan orientasi akhir dalam koordinasi antara pengawas dan kepala madrasah.

Dengan demikian, dipahami bahwa kehadiran lembaga pendidikan dasar setingkat dengan MIN 1 Aceh Tenggara merupakan motivasi eksternal bagi madrasah dalam upaya mewujudkan pendidikan dasar bermutu dengan SDM yang unggul, baik mencetak guru yang berprestasi maupun lulusan (peserta didik) yang mumpuni sesuai dengan kebutuhan masyarakat.

\section{SIMPULAN}

Berdasarkan pemaparan di atas, disimpulkan bahwa (1) koordinasi pengawas dan kepala madrasah berjalan dengan baik melalui program tahunan dalam meningkatkan kinerja guru; (2) implementasi koordinasi mencakup kegiatan pengamatan dan kunjungan kelas, rapat kepengawasan dan kegiatan pelatihan terhadap guru; dan (3) terdapat hambatan dalam upaya koordinasi, yaitu kompetisi dengan lembaga pendidikan setingkat lainnya dalam aspek mutu dan lulusan. Atas dasar kesimpulan ini, disarankan bagi kemenag Kab. Aceh Tenggara (melalui Kasi. Pendidikan Madrasah) untuk mengadakan kegiatan rutin tahunan bagi pengawas dan kepala madrasah dalam berkoordinasi terkait madrasah yang diawasi atau disupervisi. Sehingga, terdapat keseimbangan informasi dan upaya yang serentak dalam meningkatkan mutu madrasah dari lembaga setingkat lainnya.
Begitupun, penelitian ini belum dapat memenuhi segala bidang kajian riset terkait koordinasi pengawas dan kepala madrasah sebab keterbatasan peneliti. Untuk itu, direkomendasikan penelitian selanjutnya menganalisa koordinasi antara pengawas dan kepala madrasah dalam lingkup Kabupaten untuk mengoptimalkan bentuk pengawasan madrasah di Kabupaten Aceh Tenggara.

\section{DAFTAR PUSTAKA}

Abubakar, A. (2018). Koordinasi Guru PAI dan Pengawas dalam Meningkatkan Kualitas Pembelajaran padaSMPdiPapuaBarat"Educandum,4(1).

Abusmar. (2011). Pelaksanaan Supervisi Akademik oleh Kepala Sekolah dalam Meningkatkan Profesional Guru pada SMP Negeri 1 Simeulue Timur Kabupaten Simeulue. Jurnal Serambi Ilmu, 11(2). https://doi.org/10.32672/ si.v16i1.547.

Adi. (2016). Implementasi Kompetensi Manajerial Kepala Sekolah Kecamatan Kuala Kampar Kabupaten Pelalawan Provinsi Riau. Jurnal Akuntabilitas Manajemen Pendidikan, 4(1),1-16. https:/ / doi.org/10.21831/amp.v4i1.8194.

Agustina, E. (2017). Supervisi Pengawasan dan Kepala Madrasah dalam Meningkatkan Kinerja Guru Mata Pelajaran Rumpun PAI di MIN 1 Tanggamus Kabupaten Tanggamus. Tesis. Lampung: UIN Raden Intan Lampung. http://repository.radenintan. ac.id/208/.

Ahmad, E. (2019). Upaya Meningkatkan Kompetensi Pedagogik Guru dalam Menerapkan Proses Pembelajaran Berbasis Pendekatan Saintifik Melalui Supervisi Kunjungan Kelas di SMPN 18 Dumai. Jurnal Pajar: Pendidikan dan Pengajaran, 3(4), 859-869. http://dx.doi. org/10.33578/pjr.v3i4.7519.

Alfiansyah, M., et.al. (2020). Kebijakan 
Internal Madrasah dalam Meningkatkan Mutu Pendidikan di MI Nurul Ummah Kotagede Yogyakarta. Magistra: Media Pengembangan Ilmu Pendidikan Dasar dan Keislaman, 11(1). 52-67. http://dx.doi. org/10.31942/mgs.v11i1.3460.

Assingkily, M. S. \& Mesiono. (2019). Karakteristik Kepemimpinan Transformasional di Madrasah Ibtidaiyah (MI) serta Relevansinya dengan Visi Pendidikan Abad 21. Manageria: Jurnal Manajemen Pendidikan Islam, 4(1). 147-168.https://doi.org/10.14421/ manageria.2019.41-09.

Bakar,A. (2011).Supervisi Pendidikan Agama Islam (Pembinaan Guru Agama Madrasah/Sekolah). Sosial Budaya, 8(1). 1-24.http://dx.doi.org/10.24014/ sb.v8i1.344.

Braun, V. \& Clarke, V. (2012). Thematic Analysis. In H. Cooper, P. M. Camic, D. L. Long, A. T. Panter, D. Rindskopf, \& K. J. Sher (Eds), APA handbook of research methods in psychology, Vol. 2: Research designs: Quantitative, qualitative, neuropsychological, and biological (pp. 57-71). Washington, DC: American Psychological Association.

Brotosedjati, S. (2011). Kompetensi, Motivasi Kerja dan Kinerja Pengawas TK-SD" Jurnal Ilmu Pendidikan, 17(6). http:// dx.doi.org/10.17977/jip.v17i6.2881.

Creswell,J.W.(2014).ResearchDesign Qualitative, Quantitative, andMixedMethods Approaches. California: Sage Publications, Inc.

Dukalang, L. (2019). Kepemimpinan Kepala Madrasah dan Motivasi Guru Terhadap Kinerja Pengawas" Aksara: Jurnal Ilmu Pendidikan Nonformal, 5(2): 2538.http://dx.doi.org/10.37905/ aksara.5.2.81-88.2019.

Fikriah. (2019). Peran Strategis Pengawas dalam Penjaminan Mutu Madrasah. Prosiding Semdi-UNAYA (Seminar Nasional Multi Disiplin Imu UNAYA), 3(1). http://103.52.61.43/index.php/ semdiunaya/article/view/713.
Hadi, S. (2019). Analisis Kinerja Pengawas Madrasah Aliyah Kabupaten Ogan Komering Ulu Timur Sumatera Selatan. Disertasi. Lampung: UIN Raden Intan Lampung. http://repository.radenintan. ac.id/7399/.

Handayaningrat, S. (2010). Pengantar Studi Ilmu Administrasi dan Manajemen. Cet. VI. Jakarta: PT Gunung Agung.

Handoko, T. Hani. (2003). Manajemen (Edisi Kedua, Cet. XVIII). Yogyakarta: BPFEYogyakarta.

Hasbullah, M. (2015). "Hubungan Persepsi Guru Terhadap Supervisi dan Koordinasi Tugas Kepala Madrasah dengan Efektivitas Pembelajaran pada Madrasah Tsanawiyah Negeri Kabupaten Langkat" Tesis. Medan: UIN Sumatera Utara Medan. http:// repository.uinsu.ac.id/1676/.

Hasibuan, Malayu S.P. (2018). Manajemen Dasar, Pengertian dan Masalah (Edisi Revisi). Jakarta: Bumi Aksara.

Hasibuan, M. SP. (2018). Organisasi Motivasi Dasar Peningkatan Produktivitas. Jakarta: Bumi Aksara.

Hinawan, A. (2017). Sinergi Pengawas dan Kepala Sekolah dalam Upaya Meningkatkan Kinerja Guru PAI SMP di Kecamatan Panggang Gunungkidul. Tesis. Yogyakarta: Universitas Islam Indonesia.https://dspace.uii.ac.id/ handle/123456789/5044.

Ismahun. (2017). "Pengaruh Supervisi Kepala Madrasah dan Pengawas Terhadap Kinerja Guru dalam Aspek Perencanaan Pembelajaran di MTs se-Kabupaten Pati Tahun Pelajaran 2016/2017" Tesis. Jepara: UNISNU Jepara.http://eprints.unisnu. ac.id/1474/.

Leavy, P. (2017). Research Design Quantitative, Qualitative, Mixed Methods, Arts-Based, and Community-Based Participatory Research Approaches. New York: The Guilford Press. 
Ma'sum, T. (2019). Mencetak Guru Berkarakter Melalui Supervisi Pendidikan Berbasis Profetik. Al-Idaroh: Jurnal Studi Manajemen Pendidikan Islam, 3(1): 50-71. https://jurnal.stituwjombang.ac.id/index. php/al-idaroh/article/view/43.

Makmurrizal, et.al. (2016). Pelaksanaan Supervisi oleh Pengawas Sekolah dalam Meningkatkan Kompetensi Profesionalisme Guru pada SMA Negeri 2 Bandar Baru Pidie Jaya. Jurnal Administrasi Pendidikan, 4(3). 59-70. http:/ / e-repository. unsyiah.ac.id/JAP/article/view/4801.

Maqdisiana, A. (2014). "Profil Kinerja Pengawas Madrasah (Studi Kasus di Kementerian Agama Kota Bandar Lampung)" Skripsi. Lampung: UNILA. http://digilib.unila.ac.id/3422/.

Marantika \&Dahlan.D.N.A.(2019). Pengaruh Kepemimpinan Visioner Kepala Madrasah Terhadap Kedisiplinan Guru di MAN 2 Samarinda. Al-Mudarris: Jurnal Ilmiah Pendidikan Islam, 2(2). 138-153. https:// doi.org/10.23971/mdr.v2i2.1523.

Martoyo, S. (2012). Manajemen Sumber Daya Manusia, cet. IV. Yogyakarta: BPFE Yogyakarta.

Maujud, F. (2018). Implementasi Fungsifungsi Manajemen dalam Lembaga Pendidikan Islam (Studi Kasus Pengelolaan Madrasah Ibtidaiyah Islahul Muta'allim Pagutan. Jurnal Penelitian Keislaman, 14(1). 31-51. https://doi. org/10.20414/jpk.v14i1.490.

Mufidah, N. (2017). Peran Manajer Kepala MIN Jejeran Bantul dalam Implementasi Manajemen Berbasis Madrasah. Manageria: Jurnal Manajemen Pendidikan Islam, 2(1). 45-62. https://doi. org/10.14421/manageria.2017.21.03.

Munawarah, et.al. (2017). Koordinasi Pengawas dan Kepala Sekolah dalam Pelaksanaan Supervisi Pendidikan pada SD Negeri Lampeuneurut Kabupaten Aceh Besar" Jurnal Administrasi Pendidikan, 5(2). 116-120. http://e-repository. unsyiah.ac.id/JAP/article/view/8360.
Mustafa, Subhan. (2013). Upaya Pengawas dan Kepala Sekolah dalam Meningkatkan Profesionalitas Guru di MTs Alkhairaat Bambaloka Kabupaten Mamuju Utara. Tesis. Makassar: UIN Alauddin Makassar. http://repositori. uin-alauddin.ac.id/2861/.

Ndapaloka, V., et.al. (2016). Pengaruh Supervisi Akademik Pengawas dan Kepemimpinan Kepala Sekolah Melalui Motivasi Berprestasi Sebagai Mediasi Terhadap Kinerja Guru SMK Negeri Kabupaten Ende" Educational Management, 5(1). 42-54. https://journal. unnes.ac.id/sju/index.php/eduman/ article/view/12956.

Ndraha, T. (2011). Kybernology (Ilmu Pemerintahan Baru). Jakarta: Rineka Cipta.

Rahmayanti, et.al. (2014). "Kemampuan Kepala Sekolah dalam Pelaksanaan Supervisi Pengajaran di SD Negeri 24 Banda Aceh" Jurnal Ilmiah Didaktika, 14(2). http://dx.doi.org/10.22373/jid. v14i2.509.

Repina, R. (2012). Koordinasi Pengawas dan Kepala MadrasahdalamMeningkatkan Prestasi Kerja Guru MTsN Rukoh Kota Banda Aceh. 13(1). 16-25. https://doi. org/10.32672/si.v13i1.1040.

Rivai, Veithzal. (2014). Manajemen Sumber Daya Manusia untuk Perusahaan: dari Teori ke Praktik. Jakarta: PT Rajagrafindo Persada.

Rosidah, et.al. (2014). Profil Kinerja Pengawas Madrasah Kementerian Agama Lampung Selatan. Jurnal Manajemen Mutu Pendidikan, 2(2). 100-112. http://jurnal. fkip.unila.ac.id/index.php/JMMP/article/ view/5482.

Sahar, A. (2015). Efektivitas Pelaksanaan Supervisi Akademik Pengawas dalam Meningkatkan Kompetensi Profesional Guru PAI di SD Kecamatan Prambanan Sleman. Tesis. Surakarta: IAIN Surakarta. http://eprints.iain-surakarta.ac.id/10/.

Sudino, et.al. (2018). Kompetensi Manajerial Kepala Madrasah dalam Meningkatkan 
Akreditasi Madrasah Tsanawiyah Tarbiyah Islamiyah Kecamatan Kateman Kabupaten Indragiri Hilir Provinsi Riau. Tesis. Jambi: UIN Sulthan Thaha Saifuddin Jambi. http://repository.uinjambi.ac.id/752/.

Sudirman, et.al. (2017). Manajemen Pengawas pada Kantor Kementerian Agama Kabupaten Simeulue. Jurnal Administrasi Pendidikan, 5(3). 154-160. http://www. jurnal.unsyiah.ac.id/JAP/article/ view/9023.

Sumarto. (2016). Tugas Profesional Kepala Madrasah Sebagai Supervisor dalam Meningkatkan Mutu Pendidikan. Riayah, 1(2).168-187.https://doi.org/10.32332/ riayah.v1i02.109.

Syafaruddin, et.al. (2020). Manajemen Pembelajaran Pendidikan Agama Islam di SDIT Bunayya Pandan Kabupaten Tapanuli Tengah. 32-45. Auladuna: Jurnal Pendidikan Dasar Islam, 7(1). http:// repository.uinsu.ac.id/8966/.

Syawal, Julkarnain \& Badrun Kartowagiran. (2013). Evaluasi Kinerja Pengawas Sekolah dalam Melakukan Supervisi Penyelenggaraan Pendidikan SD di Kota Tidore Kepulauan. Jurnal Evaluasi Pendidikan, 1(2). 208-222. http://journal. student.uny.ac.id/ojs/index.php/jep/ article/view/67.

Tanaka, Ahmad. (2018). Keharusan Memajukan Madrasah. Jurnal Pendidikan Teknologi Madrasah, 1(2). 164-174. http://journal. iaialmawar.ac.id/index.php/jtpm/ article/view/122.

Ulum, M Bustanul. (2018). Urgensi Supervisi Pendidikan di Sekolah. Falasifa: Jurnal Studi Keislaman, 9(2): 127-134. https:// doi.org/10.36835/ falasifa.v9i2.127.

Zulfahmi, Junias. (2014). Penyusunan Program Supervisi Pendidikan pada Madrasah Kabupaten Nagan Raya. Jurnal Ilmiah Peuradeun, 2(1). 131-148. https://www. journal.scadindependent.org/index. $\mathrm{php} /$ jipeuradeun/article/view/16 